\title{
Behavioral ecology and sociobiology in post-truth society
}

\author{
James F. A. Traniello ${ }^{1}$ Theo C. M. Bakker ${ }^{2}$
}

Published online: 1 April 2017

(C) Springer-Verlag Berlin Heidelberg 2017

William Whewell (1833) coined the term scientist to describe experts in the study of natural phenomena. "Nature," he wrote, "is a collection of facts governed by laws....To ascertain such laws of nature is the peculiar business of science." Today, scientists practice in a post-truth society in which troubling, and often disturbing, attitudes toward science have become commonplace. Science is being marginalized and suppressed (Vernon 2017). Concerns are raised about risks of human endangerment resulting from the disregard of science (Gross 2017). Parallels are drawn between the dissemination and growth of "fake news" and the spread of disease (Kucharski 2016). Higgins (2016) sounds the alarm: "Scientists ... should be shocked by the idea of post-truth, ... speak up when scientific findings are ignored,... keep reminding society of the importance of the social mission of science ....(and) publicly affirm the intellectual virtues (of) critical thinking, sustained inquiry and revision of beliefs on the basis of evidence."

Behavioral ecologists and sociobiologists (herein behavioral ecologists) are scientists who seek to discover "laws of nature" governing the evolution and mechanisms of adaptive behavior by applying scientific methods. The work of behavioral ecologists is evidence-based and reflects sustained critical thinking to evaluate alternative hypotheses, not alternative facts. Like all scientists, behavioral ecologists are frustrated and distressed by the deconstruction of factual evidence and

James F. A. Traniello

jfat@bu.edu

1 Department of Biology, Boston University, 5 Cummington Mall, Boston, MA 02215, USA

2 Institute for Evolutionary Biology and Ecology, University of Bonn, An der Immenburg 1, 53121 Bonn, Germany the falsehoods and hoaxes that have virtually become everyday occurrences. Although the study of climate change has been the target of most high-profile assaults, skepticism is not restricted to atmospheric science or limited to specific research agendas. Online journalists attempt to throw truth and reality into question and undermine all science by challenging the peer review process. This attack on how ideas are critically evaluated, how data are validated, and the nature of proof is insidious.

What should behavioral ecologists do in the present social environment of denialism? How should we respond to science "losing its relevance as a source of truth" (Makri 2017)? The answer is that we should preach what we practice in a unified voice that is loud and clear. The study of adaptive behavior and its evolutionary history has deep meaning and global significance. We should persuasively state our case at every opportunity and create novel platforms to engage the public.

Behavior is central to all human endeavor and meaning. It integrates biology, social science, and the humanities and provides common ground to support innovative inquiry across academic disciplines (Wilson 1998). Behavior defines the nature of our humanity and sociality. Our understanding of universal traits such as altruism, cooperation, mate attraction and choice, parenting, consciousness, cognition, aggression, and social stress, among others (Snowdon 2003), benefits from scientific analysis. The current significance of human actionsincluding modern maladaptive behaviors - can best be understood by considering their historical origin in natural environments of adaptation and the conservation of ancestral genetic architectures (Liedtke et al. 2011).

The ecology of behavior is central to medicine and disease. Drug discovery is intrinsically linked to chemical ecology, which is founded in the natural history of herbivory and plant defenses (Caporale 1995; Meinwald and Eisner 2008). Behavioral assessments, informed by ecology, have been 
important in identifying molecules of pharmacological value. Additionally, basic research on social affiliation using nontraditional model systems may have translational implications (Young and Barrett 2015). And as a "window on the brain," behavior enables neuroscience to identify the functional circuity of a remarkably complex organ system. Here, nontraditional model systems have also proven insightful (Marder 2002) and today, neurobiological research incorporates ecological and evolutionary analysis (Catania 2012). As a mechanism of environmental interaction, behavior underscores competition, predation, infection spread and control, and population dynamics and is a sentinel for impacts of anthropogenic change. Behavioral ecology is highly relevant to basic and applied conservation (Caro 1998; Caro and Sherman 2013; Wong and Candolin 2015).

Behavioral ecology has deep roots, traceable to the great debates between Georges Cuvier and Étienne Geoffroy SaintHilaire in the nineteenth century (Jaynes 1969). It has emerged as a highly successful and broadly influential science. Ethology, the parent science of behavioral ecology, was recognized in 1973 when Karl von Frisch, Konrad Lorenz, and Niko Tinbergen were awarded the Nobel Prize in Physiology or Medicine. The award tacitly acknowledged the significance of behavioral ecology through the recognition of Tinbergen's pioneering studies of the adaptive significance and evolutionary history of behavior (Tinbergen 1963). Sociobiology: The New Synthesis (Wilson 1975) has been called the most important book on animal behavior of all time. On Human Nature (Wilson 1978) received a Pulitzer Prize. Sociobiological theory has since penetrated psychology, medicine, psychiatry, neuroscience, ecotoxicology, anthropology, political science, philosophy, religion, and music. Today, the integrative, diverse, and intellectually rich disciplines of behavioral ecology and sociobiology flourish (Bakker and Traniello 2016; Simmons 2014).

There is a pervasive need for the public to be able to recognize the importance of scientists and the need to be literate in science (Maienschein 1998) and evolution (Lerner 2000). This is a necessity, rather than an enrichment, in education. Basic science literacy impacts the understanding of climate change (Kahan et al. 2012) and informs public viewpoints of all other human challenges that will likely be resolved by the scientific community. Lerner (2000) notes that "those who do not have the scientist's special knowledge, skills and experience cannot have equal voice in achieving a scientific consensus." Science can be made more democratic through outreach programs initiated by behavioral ecologists. Behavioral ecologists must play a prominent role in ensuring a well-informed electorate. In these difficult times, we need to stay on message.
Acknowledgements We thank B. Moran, I. Traniello, and Dr. S. Arganda for insights and comments.

\section{References}

Bakker TCM, Traniello JFA (2016) Behavioral Ecology and Sociobiology at 40. Behav Ecol Sociobiol 70:1991-1993

Caporale LH (1995) Chemical ecology: a view from the pharmaceutical industry. P Natl Acad Sci USA 92:75-82

Caro T (1998) Behavioral ecology and conservation biology. Oxford University Press, New York

Caro T, Sherman P (2013) Eighteen reasons animal behaviourists avoid involvement in conservation. Anim Behav 85:305-312

Catania KC (2012) The evolution of brains and behavior for optimal foraging: a tale of two predators. P Natl Acad Sci USA 109: 10701-10708

Gross M (2017) The dangers of a post-truth world. Curr Biol 27:R1-R18

Higgins K (2016) Post-truth: a guide for the perplexed. Nature 540:9

Jaynes J (1969) The historical origins of "ethology" and "comparative psychology." Anim Behav 17:601-606

Kahan D, Peters E, Wittlin M, Slovi P, Ouellette L, Braman D, Mandel G (2012) The polarizing impact of science literacy and numeracy on perceived climate change risks. Nat Clim Chang 2:732-735

Kucharski A (2016) Post-truth: study epidemiology of fake news. Nature 540(7634):525-525

Lerner LS (2000) Good and bad science in US schools. Nature 407:287290

Liedtke WB, McKinley MJ, Walker LL, Zhang H, Pfenning AR, Drago J, Hochendoner SJ, Hilton DL, Lawrence AJ, Denton DA (2011) Relation of addiction genes to hypothalamic gene changes subserving genesis and gratification of a classic instinct, sodium appetite. P Natl Acad Sci USA 108:12509-12514

Maienschein J (1998) Scientific literacy. Science 281:917-917

Makri A (2017) Give the public the tools to trust scientists. Nature 541(7637):261-261

Marder E (2002) Non-mammalian models for studying neural development and function. Nature 417:318-321

Meinwald J, Eisner T (2008) Chemical ecology in retrospect and prospect. P Natl Acad Sci USA 105:4539-4540

Simmons LW (2014) 25 years of Behavioral Ecology. Behav Ecol 25:1-3

Snowdon CT (2003) Significance of animal behavior research. In: Bekoff $M$ (ed) Encyclopedia of animal behavior, Vol. 1. Greenwood Publishing Co, Phoenix, pp 156-161

Tinbergen N (1963) On aims and methods of ethology. Z Tierpsychol 20: 410-433

Vernon JL (2017) Science in the post-truth era. Am Sci 105:2

Whewell W (1833) Astronomy and general physics considered with reference to natural theology (Bridgewater treatise). William Pickering, London

Wilson EO (1975) Sociobiology: the new synthesis. Harvard University Press, Cambridge

Wilson EO (1978) On human nature. Harvard University Press, Cambridge

Wilson EO (1998) Consilience: the unity of knowledge. Random House, New York

Wong BBM, Candolin U (2015) Behavioral responses to changing environments. Behav Ecol 26:665-673

Young LJ, Barrett CE (2015) Can oxytocin treat autism? Science 347: $825-826$ 